\title{
Recent advances in the management of hyponatremia in cancer patients
}

\author{
Maryam I. Khan ${ }^{1}$, Steven G. Waguespack², Intekhab Ahmed ${ }^{3}$ \\ 'Division of Endocrinology, Diabetes and Metabolism, Jefferson Health, Voorhees, NJ 08043, USA. \\ ${ }^{2}$ Department of Endocrine Neoplasia and Hormonal disorders, University of Texas M.D. Anderson Cancer Center, Houston, TX \\ 77030, USA. \\ ${ }^{3}$ Division of Endocrinology, Diabetes and Metabolism, Jefferson Health, Philadelphia, PA 19107, USA.
}

Correspondence to: Dr. Maryam I. Khan, Division of Endocrinology, Diabetes and Metabolism, Jefferson Health, 333 Laurel Oak, Road Voorhees, NJ 08043, USA. E-mail: maryamijazkhan@gmail.com

How to cite this article: Khan MI, Waguespack SG, Ahmed I. Recent advances in the management of hyponatremia in cancer patients. J Cancer Metastasis Treat2019;5:71. http://dx.doi.org/10.20517/2394-4722.2019.017

Received: 1 Jul 2019 First Decision: 20 Aug 2019 Revised: 16 Oct 2019 Accepted: 16 Oct 2019 Published: 30 Oct 2019

Science Editor: Rossana Berardi Copy Editor: Jing-Wen Zhang Production Editor: Tian Zhang

\begin{abstract}
Hyponatremia is the most frequently encountered electrolyte disorder in cancer patients and is usually multifactorial in its origin. In this review, we discuss the predisposing factors, pathophysiology, clinical symptomatology, and currently available diagnostic and therapeutic options for the management of hyponatremia. In addition to paraneoplastic syndromes, concurrent chemotherapy and comorbidities predispose oncology patients to the risk of hyponatremia. Initial symptoms and signs can be subtle and the prompt evaluation and initiation of treatment is of paramount importance to prevent neurocognitive and other complications. The syndrome of inappropriate antidiuresis (SIAD) is the most common cause of hyponatremia, and the use of serum and urine parameters that distinguish SIAD from other etiologies is discussed. Individualized treatment is preferred depending on the underlying cause and severity of hyponatremia. The treatment of hyponatremia is reviewed and the importance of avoiding rapid overcorrection of the sodium level to reduce the risk of osmotic demyelination syndrome is emphasized. Vasopressin receptor antagonists (vaptans) offer a direct approach to the management of euvolemic and hypervolemic hyponatremia, but the indications for their use and long-term safety need to be clarified. The treatment of hyponatremia is likely to reduce complications and improve survival in cancer patients.
\end{abstract}

Keywords: Hyponatremia, electrolyte abnormalities, dysnatremias, cancer

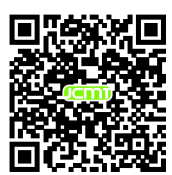




\section{INTRODUCTION}

Dysnatremias are common electrolyte imbalances in cancer patients ${ }^{[1]}$. Hyponatremia (serum sodium $<135 \mathrm{mEq} / \mathrm{L}$ ) is the most common electrolyte abnormality encountered in clinical practice. Oncology patients are particularly at risk of developing hyponatremia due to their underlying cancer (including associated paraneoplastic syndromes), predisposition to infections, antibiotic use, concurrent chemotherapy, and nausea and pain. Hyponatremia in cancer patients is a predictor of outcome, hospital length and cost of stay, and an independent predictor of mortality in the intensive care unit ${ }^{[2-5]}$. The syndrome of inappropriate antidiuresis (SIAD) is a frequent cause of cancer related hyponatremia ${ }^{[6]}$. Hyponatremia due to ectopic arginine vasopressin (AVP; also known as antidiuretic hormone or ADH) production has been identified in $24.6 \%$ of small cell lung cancer patients and is associated with shorter survival $^{[7]}$. After brain metastasis, hyponatremia is the second leading cause of neurologic disorders in patients with small cell lung cancer ${ }^{[8]}$. Other malignancies with a high prevalence of hyponatremia include gastrointestinal, hematological, breast and urological malignancies ${ }^{[9]}$. Many chemotherapeutic agents coupled with hydration protocols can cause hyponatremia. Concomitant use of thiazide diuretics ${ }^{[10]}$ and opioid derivatives used for the management of cancer-related pain increase AVP release and contribute to hyponatremia ${ }^{[5]}$. Vincristine and vinblastine have neurotoxic effects on the hypothalamic-pituitarythyroid axis and cause hyponatremia while cyclophosphamide enhances the effect of AVP on the kidneys. Furthermore, cisplatin and carboplatin stimulate production of AVP and inhibit absorption of sodium by renal tubules. Treatment strategies with targeted therapies (inhibitors of angiogenesis, anti-epithelial growth factor tyrosine kinase receptor inhibitors and monoclonal antibodies) in cancer patients increases the incidence of hyponatremia $(25.5 \%)$ in the treatment group. Higher incidence of hyponatremia is observed with a treatment combination of cetuximab and brivanib (63.4\%) as well as with pazopanib $(31.7 \%)^{[11]}$. Patients receiving chemotherapy generally increase their free water intake. In small cell lung cancer patients receiving chemotherapy, tumor lysis syndrome increases the risk of hyponatremia due to increased release of AVP. In this clinical situation hyponatremia could be prevented by water restriction before the start of chemotherapy.

In cases of symptomatic hyponatremia, pharmacologic intervention may be necessary to increase serum sodium levels ${ }^{[8]}$. The management of hyponatremia is becoming increasingly important in oncology due to the negative correlation of hyponatremia with performance status and the prognosis of cancer ${ }^{[7,11]}$. Treatment of hyponatremia in small cell lung cancer patients is associated with improved survival ${ }^{[12]}$. Sodium normalization is an independent prognostic factor for improved overall survival and progression free survival in patients with advanced non-small cell cancer with hyponatremia treated with first line chemotherapy or targeted therapy ${ }^{[11]}$. Failure to identify the potential cause of hyponatremia and delay in appropriate treatment plan places the patient at risk of an adverse outcome. In this review, we discuss the initial evaluation, diagnostic algorithm and treatment of hyponatremia in cancer patients.

\section{CLINICAL PRESENTATION}

Symptoms of hyponatremia have variable clinical presentations, can be nonspecific and confounded by other comorbidities, and can range from mild cognitive deficits to severe neurologic symptoms. Symptoms of mild hyponatremia are nonspecific and may manifest as malaise, anorexia, muscle cramps, nausea, confusion, lethargy, and headache. More severe neurologic manifestations such as vomiting, somnolence, seizures, respiratory arrest, coma, and death are due to cerebral edema. Symptoms are often subtle, if present at all, in patients with chronic hyponatremia in which the brain has had time to adapt to the hypotonic state. Chronic hyponatremia is associated with falls and increased risk of fracture ${ }^{[13]}$. A rapid decrease in serum sodium induces symptoms at a higher sodium level and the severity of symptoms reflect the degree of brain edema and guide the urgency of management. Patients with acute hyponatremia are at risk of permanent neurologic impairment. 


\section{PATHOPHYSIOLOGY OF HYPONATREMIA}

Hyponatremia denotes a state of relative excess free water in relation to sodium in conjunction with impaired free water excretion. AVP regulates water balance in the body. AVP release is regulated by changes in effective osmolality or hypotonicity. Sodium is the major determinant of serum osmolality. Osmoreceptors, located in the anterior hypothalamus, detect changes in effective serum osmolality and regulate the release of vasopressin and thirst. An increase in serum osmolality activates osmoreceptors leading to secretion of vasopressin from the posterior pituitary. The threshold for releasing vasopressin is lower than for triggering thirst to avoid persistent thirst ${ }^{[10]}$. Hyponatremia is a state of low effective serum osmolality or hypotonicity. Effective serum osmolality refers to the number of osmoles that contribute water movement between intracellular and extracellular compartments determined by the relative solute permeability properties of the membranes separating the compartments. Total osmolality reflects the concentration of all solutes in a given weight of water $(\mathrm{mOsm} / \mathrm{kg})$ regardless of the permeability properties of the separating membrane. A calculated serum osmolality [calculated serum osmolality $(\mathrm{mOsm} / \mathrm{kg})=2 \times$ $\mathrm{Na}(\mathrm{mEq} / \mathrm{L})+$ glucose $(\mathrm{mg} / \mathrm{dL}) / 18+$ urea $(\mathrm{mg} / \mathrm{dL}) / 2.8]<275 \mathrm{mOsm} / \mathrm{kg}$ could refer to isotonic, hypotonic or hypertonic hyponatremia, depending on which osmoles are included in the formula, whereas a measured serum osmolality $<275 \mathrm{mOsm} / \mathrm{kg}$ always indicates hypotonic hyponatremia.

Clarification of tonicity is important because isotonic hyponatremia does not cause cerebral edema. The basolateral membrane of the renal collecting duct is permeable to water (aquaporin-3 and aquaporin-4 water channels). Vasopressin acts at the vasopressin-2 receptor on the cells of the renal collecting duct leading to fusion of acquaporin-2 in the apical membrane allowing water to enter into the cells of the collecting duct and ultimately to the circulation. Reabsorption of water from the collecting duct increases the concentration of sodium and other electrolytes in the urine, and concentrates urine. Low serum osmolality (normal range 285-295 mOsm $/ \mathrm{kg}$ ) decreases vasopressin release leading to excretion of free water from renal tubules. Patients with a reset osmostat, as seen in hypovolemia (baroreceptor stimulation), quadriplegia, and psychosis, have mild hyponatremia that is unresponsive to changes in fluid and water intake. Patients with a reset osmostat excrete $80 \%$ of a water load (10-15 mL/kg given orally or intravenously) within four hours, while patients with SIAD have impaired water excretion. Fractional excretion of urate [FEurate $(\%)=($ urine urate $\times$ serum $\mathrm{Cr}) /($ serum urate $\times$ urine $\mathrm{Cr}) \times 100]$ is also normal $(4 \%-11 \%)$ in patients with a reset osmostat while patients with SIAD have elevated FEurate $(>11 \%)^{[14]}$. Identification of a reset osmostat is important because the risk of severe hyponatremia is low. In addition, treatment is not necessary and likely to be ineffective, since bringing sodium to the normal range will increase thirst ${ }^{[15]}$. Since AVP release is controlled by hemodynamic and nonhemodynamic stimuli, cancer patients are at risk of hyponatremia due to hemodynamic (hypovolemia, hypotension, congestive heart failure, and nephrotic syndrome) and non-hemodynamic stimuli (pain, stress, nausea, vomiting, hypoxemia, hypercapnia, perioperative state and infections) ${ }^{[16]}$.

Pseudohyponatremia (a lab artifact) is due to an inaccurate measurement of sodium in the presence of abnormally high concentration of proteins and lipids in the blood. Larger relative proportion of plasma is occupied by excessive lipids and proteins. In this situation, serum osmolality is actually in the normal range since total number of solutes in the plasma remain the same. Monoclonal gammopathies can also cause pseudohyponatremia ${ }^{[10]}$. Patients undergoing urological and gynecological surgery can have high serum osmolality due to mannitol and glycine absorbed in the circulation during irrigation. Effective osmoles, e.g., mannitol, glycine and glucose (seen in uncontrolled diabetes), increase serum osmolality by shifting water from intracellular compartments.

\section{CLASSIFICATION OF HYPONATREMIA}

Hyponatremia is classified on the basis of biochemical severity, rapidity of onset, development of symptoms, measured serum osmolality, and volume status. Acute hyponatremia is defined as hyponatremia that is 
documented to exist $<48 \mathrm{~h}$. The risk of cerebral edema increases in patients with acute hyponatremia since brain cells have less time to adapt to a hypotonic environment. Conditions predisposing cancer patients to acute hyponatremia include a postoperative state (especially after prostate and uterine surgery), polydipsia, thiazide diuretics, and infusion of cyclophosphamide. Brain cells adapt to hyponatremia by extruding sodium, chloride, and organic osmoles from cells. After adaptation, a rapid increase in serum sodium, as potentially seen after hypertonic saline administration, can cause damage to the myelin sheath leading to osmotic demyelination. In most clinical situations in which the duration of hyponatremia is less clear, hyponatremia should be considered chronic and managed accordingly to avoid the risk of osmotic demyelination ${ }^{[10]}$. Mild hyponatremia refers to serum sodium levels ranging from $130 \mathrm{mEq} / \mathrm{L}$ to $135 \mathrm{mEq} / \mathrm{L}$; moderate hyponatremia refers to serum sodium levels ranging from $125 \mathrm{mEq} / \mathrm{L}$ to $129 \mathrm{mEq} / \mathrm{L}$; profound hyponatremia refers to serum sodium levels $<125 \mathrm{mEq} / \mathrm{L}$. Assessment of volume status in hyponatremia is challenging because of the variability in individual clinical assessment. Furthermore, in this context it should be clarified whether volume status refers to effective circulating volume, total body water or extracellular fluid ${ }^{[10]}$. In addition to absolute serum sodium levels, other factors that guide treatment of hyponatremia include symptoms and the rate of development of hyponatremia.

\section{EUVOLEMIC HYPONATREMIA}

Euvolemic hyponatremia results from low solute intake or SIAD and is a major cause of hyponatremia in cancer patients. Several malignancies are associated with SIAD. SIAD results from the abnormal production (increased release from the neurohypophysis or ectopic production) or action of AVP resulting in an excess of total body free water relative to sodium. SIAD is defined by hyponatremia (serum $\mathrm{Na}$ $<135 \mathrm{mEq} / \mathrm{L}$ ) and an inappropriately concentrated urine (urine osmolality > $100 \mathrm{mOsm} / \mathrm{kg}$, usually > $300 \mathrm{mOsm} / \mathrm{kg})$ in the presence of low serum osmolality $(<275 \mathrm{mOsm} / \mathrm{kg})$, euvolemia, and normal renal function. Renal sodium excretion is increased (usually $>30 \mathrm{mEq} / \mathrm{L}$ in a random urine sample) due to decreased aldosterone production and possibly increased secretion of natriuretic peptides ${ }^{[17,18]}$, which helps to distinguish SIAD from hypovolemic and hypervolemic hyponatremia. Urine sodium is typically $<30 \mathrm{mEq} / \mathrm{L}$ in hypovolemic and hypervolemic hyponatremia, unless there is an underlying process contributing to renal sodium loss such as diuretic use ${ }^{[19]}$. Additional criteria that help to diagnose SIAD include serum osmolality less than the urine osmolality, low serum uric acid $<4 \mathrm{mg} / \mathrm{dL}$ and serum blood urea nitrogen $(\mathrm{BUN})<21.6 \mathrm{mg} / \mathrm{dL}$, elevated fractional sodium excretion $>0.5 \%$, fractional urea excretion $>$ $55 \%$, and fractional uric acid excretion $>11 \%$.

Causes of SIAD are outlined in Table 1. SIAD is a diagnosis of exclusion. Other causes of euvolemic hyponatremia include adrenal insufficiency and hypothyroidism. Hematocrit levels and serum concentrations of uric acid and BUN may be decreased in SIAD $^{[20]}$ due to hemodilution. These analytes could be elevated in hypovolemic hyponatremia ${ }^{[21]}$. In the diagnosis of SIAD, diagnostic tools that are less useful, and potentially dangerous in the latter case, include AVP levels and water loading tests [Table 2]. Cancer patients can have a combination of SIAD and other processes that contribute to hyponatremia. Therefore, the management of these patients is often complicated and relies on the recognition of such comorbidities. Hyponatremia could be a marker of occult malignancy ${ }^{[22]}$. Patients with an unidentifiable cause of SIAD should have a chest X-ray. Furthermore, a chest CT should be considered in patients with a history of smoking and a MRI of the brain in patients with persistent neurologic symptoms and signs despite correction of hyponatremia ${ }^{[23]}$.

\section{HYPERVOLEMIC HYPONATREMIA}

Patients with congestive heart failure, nephrotic syndrome, liver and kidney disease can have hypotonic hyponatremia with increased extracellular fluid volume due to reduced effective arterial volume that activates baroreceptor-mediated neurohormonal release of vasopressin. Concomitant use of diuretics, 
Table 1. Causes of syndrome of inappropriate antidiuresis

\begin{tabular}{|c|c|c|c|}
\hline Tumors & Infections & Drugs & Other \\
\hline $\begin{array}{l}\text { Extrapulmonary small cell } \\
\text { carcinoma } \\
\text { Lymphoma } \\
\text { Meningeal carcinomatosis } \\
\text { Metastatic brain and spine } \\
\text { tumors } \\
\text { Olfactory neuroblastoma } \\
\text { Ovarian teratoma } \\
\text { Endometrial carcinoma } \\
\text { Pancreatic carcinoma } \\
\text { Primary brain tumors } \\
\text { Prostate carcinoma } \\
\text { Bladder carcinoma } \\
\text { Small cell lung carcinoma and } \\
\text { other pulmonary tumors } \\
\text { Thymic tumors } \\
\text { Sarcomas }\end{array}$ & $\begin{array}{l}\text { AIDS } \\
\text { Encephalitis } \\
\text { Hydrocephalus } \\
\text { Idiopathic, } \\
\text { particulary in the } \\
\text { elderly } \\
\text { Meningitis } \\
\text { Pneumonia (bacterial } \\
\text { and viral) } \\
\text { Pulmonary abscess } \\
\text { Aspergillosis } \\
\text { Tuberculosis } \\
\text { Brain abscess } \\
\text { Rocky mountain } \\
\text { spotted fever } \\
\text { Malaria }\end{array}$ & 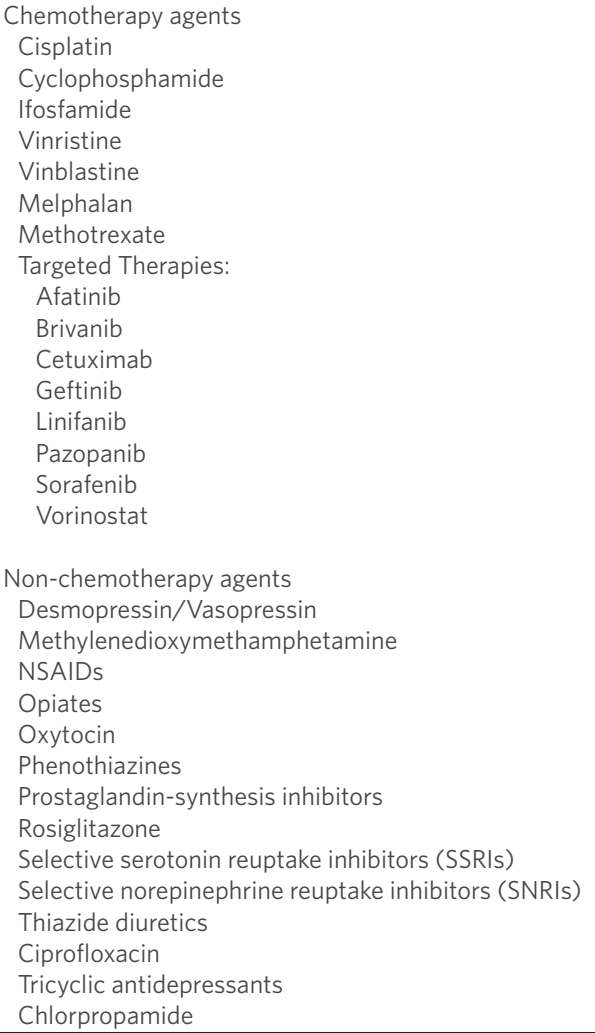 & $\begin{array}{l}\text { Postoperative state (major } \\
\text { abdominal or thoracic surgery; } \\
\text { pituitary surgery or other } \\
\text { neurosurgery) } \\
\text { Hydrocephalus } \\
\text { Cavernous sinus Thrombosis } \\
\text { Multiple sclerosis } \\
\text { Guillain-Barre Syndrome } \\
\text { Delirium Tremens } \\
\text { Acute intermittent porphyria } \\
\text { Acute respiratory failure } \\
\text { Acute Psychosis } \\
\text { Stroke } \\
\text { Subarachnoid hemorrhage and } \\
\text { other intracranial hemorrhages } \\
\text { Traumatic brain injury } \\
\text { General anesthesia } \\
\text { Nausea } \\
\text { Pain } \\
\text { Stress }\end{array}$ \\
\hline
\end{tabular}

e.g., thiazides, loop diuretics and spironolactone, may also contribute to hyponatremia. Reduced oncotic pressure in nephrotic syndrome has a similar effect due to baroreceptor-mediated neurohormonal activation. Chemotherapy induced tubulopathy decreases the ability of the kidney to excrete free water. Increased free water intake in the presence of kidney disease causes hypervolemic hyponatremia ${ }^{[10]}$.

\section{HYPOVOLEMIC HYPONATREMIA}

Reduced effective circulatory volume (as seen in pancreatitis, bowel obstruction, sepsis, diarrhea, and sweating) increases vasopressin release leading to increase water retention and hyponatremia that worsens with hypotonic volume repletion ${ }^{[10]}$.

\section{CEREBRAL SALT WASTING SYNDROME}

Cerebral salt wasting (CSW) syndrome is a clinical entity primarily but not exclusively associated with intracranial disease that leads to hyponatremia and decreased extracellular fluid volume ${ }^{[2]}$. Although most commonly described in neurosurgical patients with subarachnoid hemorrhage, CSW is also seen in cerebral neoplastic dissemination in brain metastasis ${ }^{[8]}$. However, CSW syndrome remains controversial and incompletely understood.

CSW is associated with primary overproduction of atrial natriuretic peptide and brain natriuretic peptide resulting in a decrease in sodium and water reabsorption in the kidney while reduced sympathetic outflow in intracranial disease reduces activity of renin-angiotensin system and increases natriuresis ${ }^{[25-27]}$. CSW syndrome may lead to a clinical picture similar to SIAD ${ }^{[28]}$. Laboratory findings common to SIAD and CSW syndrome include hypotonic hyponatremia, increased fractional excretion of urate (FEurate $>11 \%$ ), high urine osmolality (> $100 \mathrm{mOsm} / \mathrm{kg})$, and urine sodium $(>30 \mathrm{mE} / \mathrm{L})$ in the presence of normal thyroid, 
Table 2. Criteria for diagnosis syndrome of inappropriate antidiuresis ${ }^{[10,19]}$

\begin{tabular}{ll}
\hline \multicolumn{1}{c}{ Essential criteria } & \multicolumn{1}{c}{ Supplemental criteria } \\
\hline Serum osmolality $<275 \mathrm{mOSm} / \mathrm{kg}$ & Blood urea nitrogen $<10 \mathrm{mg} / \mathrm{dL}$ \\
Urine osmolality $>100 \mathrm{mOSm} / \mathrm{Kg}$ & Serum uric acid $<4 \mathrm{mg} / \mathrm{dL}$ \\
Clinical euvolemia: & FEurate $>11 \%$ \\
$\begin{array}{l}\text { Absence of signs of hypovolemia* and hypervolemia** } \\
\text { Central venous pressure } 6-10 \mathrm{~cm} \mathrm{H}_{2} \mathrm{O}\end{array}$ & $\mathrm{FENa}^{*}>1 \%$ \\
Urine sodium $>30 \mathrm{mEq} / \mathrm{L}$ & $\mathrm{FEurea}^{\dagger}>55 \%$ \\
No evidence of hypothyroidism, adrenal insufficiency & Correction of hyponatremia through fluid restriction \\
No diuretic use & \\
No renal insufficiency & \\
\hline
\end{tabular}

*Signs of hypovolemia (decreased skin turgor, orthostasis, dry mucus membranes, tachycardia). ${ }^{\star \star}$ Signs of hypervolemia (edema, ascites). "FEurate $(\%)=($ urine urate $\times$ serum $\mathrm{Cr}) /($ serum urate $\times$ urine $\mathrm{Cr}) \times 100$. ${ }^{\circ} \mathrm{FENa}(\%)=($ urine sodium $\times$ serum $\mathrm{Cr}) /($ serum $\mathrm{Na} \times$ urine $\mathrm{Cr}) \times 100 .{ }^{\dagger}$ FEurea $(\%)=($ urine urea nitrogen $\times$ serum $\mathrm{Cr}) /($ blood urea nitrogen $\times$ urine $\mathrm{Cr}) \times 100$

adrenal, and renal function. After normalization of hyponatremia, FEurate normalizes in patients with SIAD (FEurate $4 \%-11 \%$ ) but remains persistently elevated in CSW (FEurate $>11 \%)^{[14]}$. Clinical symptoms and signs of hypovolemia (decreased skin turgor, orthostasis, dry mucus membranes, tachycardia) and low central venous pressure in the setting of normal kidney function denote CSW. Serum AVP levels are elevated as seen in patients with hypovolemia ${ }^{[21]}$. Identification of CSW from SIAD is of paramount importance to guide appropriate therapy; aggressive volume and salt repletion in CSW versus fluid restriction in SIAD.

After correction of hypovolemia, sodium loss is repleted with sodium chloride tablets and fludrocortisone with close monitoring of serum electrolytes ${ }^{[29]}$. Rarely, hypertonic saline is required to correct hyponatremia ${ }^{[29]}$.

\section{APPROACH TO THE DIAGNOSTIC EVALUATION OF HYPONATREMIA}

The initial step in the evaluation of hyponatremia is to measure serum osmolality. If hyponatremia is associated with hypoosmolality, the next step will be to measure urine osmolality and urine sodium. SIAD is a diagnosis of exclusion after ruling out other causes of euvolemic hyponatremia such as hypothyroidism (free T4, thyrotropin stimulating hormone) and adrenal insufficiency (total cortisol, adrenocorticotropic hormone). Other causes that could be excluded in cases of hypotonic hyponatremia are decreased effective circulating blood volume and renal insufficiency ${ }^{[16]}$ [Figure 1].

Copeptin is secreted from the posterior pituitary along with AVP. There is a strong correlation between plasma AVP levels and copeptin levels. Although copeptin levels tend to be highest in small cell lung cancer, evaluation of copeptin levels between cancer-related versus non cancer-related SIAD show no significant difference. Multiple other factors (e.g., pain, nausea, stress, medications) contribute to elevated copeptin levels. Copeptin levels $>84 \mathrm{pmol} / \mathrm{L}$ indicate hypovolemic hyponatremia whereas low levels of copeptin $<3.9 \mathrm{pmol} / \mathrm{L}$ indicate primary polydipsia ${ }^{[30]}$.

\section{CLINICAL MANAGEMENT/TREATMENT OPTIONS}

Definitive treatment for hyponatremia involves treating the underlying cause. Medical therapy [Table 3] improves the serum sodium level and prevents potential neurologic complications. In patients with severe symptomatic hyponatremia, a $5 \mathrm{mEq} / \mathrm{L}$ increase of serum sodium is likely to improve clinical symptoms ${ }^{[10]}$. The serum sodium should be acutely increased $1-2 \mathrm{mEq} / \mathrm{L} / \mathrm{h}$ over $3-4 \mathrm{~h}$ using hypertonic saline (3\% $\mathrm{NaCl}$ ). To avoid the risk of over correction, current guidelines recommend i.v. infusion of $150 \mathrm{~mL}$ of $3 \%$ hypertonic saline over $20 \mathrm{~min}$, rechecking serum sodium concentration and then, if necessary, repeating the $150 \mathrm{~mL}$ of $3 \%$ hypertonic saline infusion ${ }^{[31]}$. Frequent monitoring of serum sodium along with $150 \mathrm{~mL}$ of hypertonic saline avoids rapid increase in serum sodium. Hypertonic saline can be administered at an 


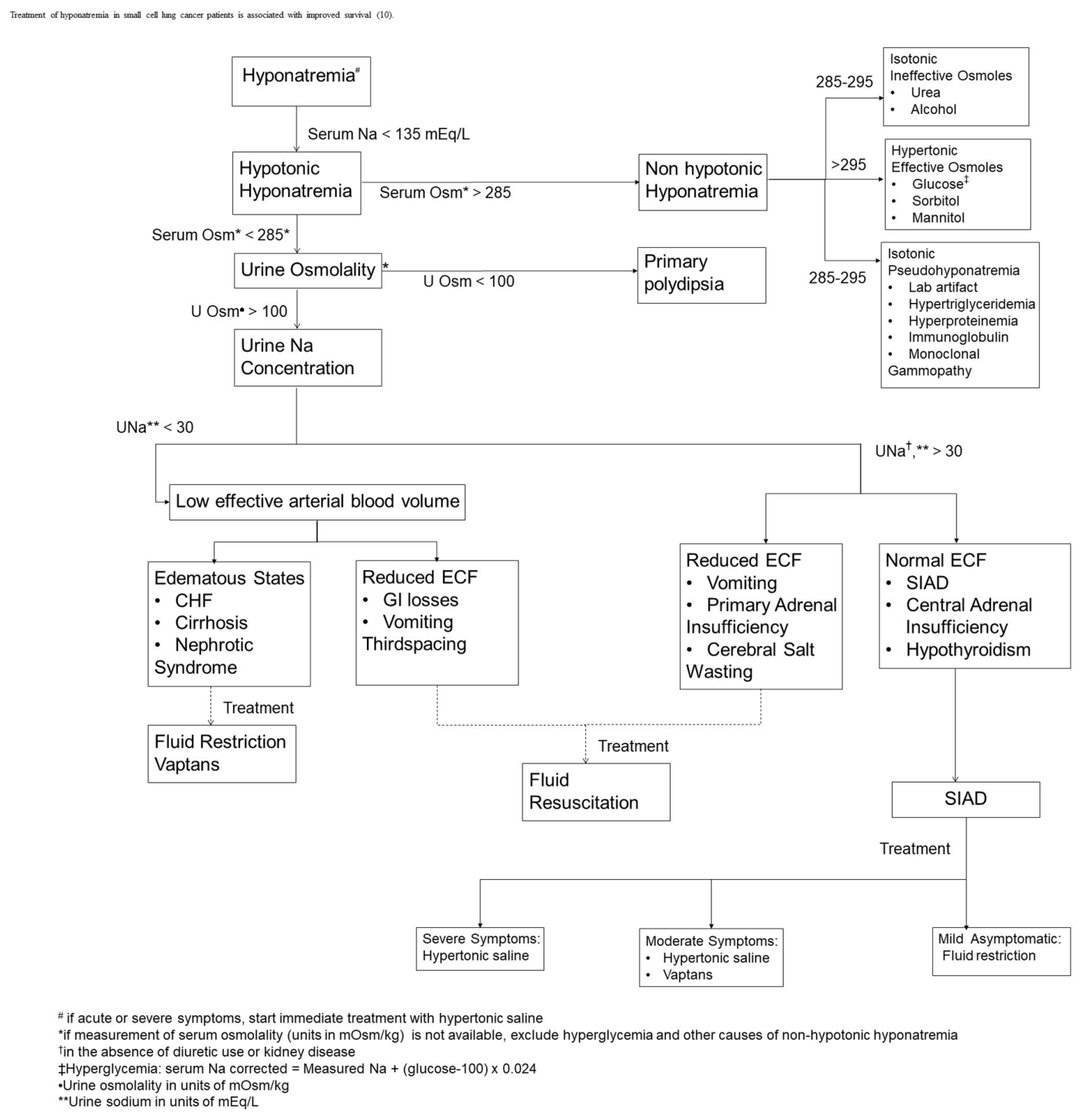

Figure 1. Evaluation of hyponatremia ${ }^{[10,19,46]}$

initial rate of $1-2 \mathrm{~mL} / \mathrm{kg} / \mathrm{h}$, although patients with seizure or coma may require a higher initial infusion rate of $2-4 \mathrm{~mL} / \mathrm{kg} / \mathrm{h}$. A total volume of $500 \mathrm{~mL}$ hypertonic saline is sufficient to increase serum sodium $5 \mathrm{mEq} / \mathrm{L}$. Hypertonic saline infusion is stopped when symptoms improve, serum sodium concentration increases by $10 \mathrm{mEq} / \mathrm{L}$ in total, or the serum sodium concentration reaches $130 \mathrm{mEq} / \mathrm{L}$. If symptoms do not improve despite an increase of serum sodium by $10 \mathrm{mEq} / \mathrm{L}$, or a serum sodium level of $130 \mathrm{mEq} / \mathrm{L}$, other etiologies for these symptoms should be explored ${ }^{[10]}$. In patients with mild symptoms, $3 \%$ saline can initially be administered at $0.5 \mathrm{~mL} / \mathrm{kg} / \mathrm{h}^{[32]}$. Furosemide in combination with hypertonic saline infusion promotes electrolyte-free water excretion ${ }^{[33]}$. The use of normal saline in the treatment of SIAD should be avoided due to the concern of net free water retention and worsening hyponatremia ${ }^{[33]}$.

In the asymptomatic patient, SIAD is initially treated with fluid restriction to $500-1000 \mathrm{~mL}$ daily $\left(1 \mathrm{~L} / \mathrm{m}^{2} /\right.$ day or $2 / 3$ maintenance in children) so that free water intake is below the capacity for kidney water excretion plus insensible losses. Intake and output should be monitored closely to ensure compliance with fluid restriction and to maintain an oral intake of at least $500 \mathrm{~mL} /$ day below the average urine volume (in adults). In patients with mild asymptomatic hyponatremia fluid restriction could be started at 1200-1500 mL. A commonly 
Table 3. Management of hyponatremia ${ }^{[10,19,46]}$

\begin{tabular}{|c|c|c|c|}
\hline Medical therapy In & Indication & Dose & Adverse effects \\
\hline Demeclocycline & $\begin{array}{l}\text { Euvolemic and hypervolemic } \\
\text { hyponatremia }\end{array}$ & $300-600 \mathrm{mg}$ bid & $\begin{array}{l}\text { Slow onset of action, acute } \\
\text { kidney injury }\end{array}$ \\
\hline Lithium & Euvolemic hyponatremia & $600-1800$ mg/day & $\begin{array}{l}\text { Narrow therapeutic window, } \\
\text { confusion and somnolence }\end{array}$ \\
\hline Fludrocortisone & Cerebral salt wasting SIAD & $0.1-0.3 \mathrm{mg} / \mathrm{day}$ & Hypokalemia, hypertension \\
\hline $\mathrm{NaCl}$ tab & Cerebral salt wasting SIAD & $1-3 \mathrm{~g} /$ day in divided doses & $\begin{array}{l}\text { Non-adherence to therapy for } \\
\text { chronic use }\end{array}$ \\
\hline Urea & Euvolemic hyponatremia & 30 g/day & $\begin{array}{l}\text { Lack of palatability, slow onset of } \\
\text { action }\end{array}$ \\
\hline Vaptans & $\begin{array}{l}\text { SIAD } \\
\text { hypervolemic hyponatremia }\end{array}$ & $\begin{array}{l}\text { Conivaptan } \\
20 \text { mg i.v. bolus over } 30 \text { min and then } 20 \text { mg i.v. infusion } \\
\text { over } 24 \text { h. Infusion rate can be increased to } 40 \text { mg daily; } \\
\text { maximum duration of treatment is } 4 \text { days. } \\
\text { Tolvaptan } \\
15 \text { and } 30 \text { mg tab for oral use. Maximum dose } 60 \mathrm{mg} \text {. } \\
\text { Therapy should be initiated in the hospital with monitoring } \\
\text { of serum sodium }\end{array}$ & $\begin{array}{l}\text { Dry mouth, increased thirst and } \\
\text { polyuria; } \\
\text { risk of rapid increase in serum } \\
\text { sodium; liver injury associated } \\
\text { with higher doses; concern for } \\
\text { increase in mortality }\end{array}$ \\
\hline $\begin{array}{ll}\text { Hypertonic saline } & \text { Ec } \\
3 \% & \text { hy }\end{array}$ & $\begin{array}{l}\text { Euvolemic hyponatremia and } \\
\text { hypervolemic hyponatremia }\end{array}$ & $\begin{array}{l}\text { Hypertonic saline } 3 \% 150 \mathrm{~mL} \text { i.v. bolus over } 20 \mathrm{~min} \times 3 \text {. } \\
\text { Check serum sodium after every bolus. } \\
\text { Hypertonic saline } 3 \% \text { continuous infusion } 1-2 \mathrm{~mL} / \mathrm{kg} / \mathrm{h}^{\star}\end{array}$ & $\begin{array}{l}\text { Osmotic demyelination } \\
\text { syndrome }\end{array}$ \\
\hline Fluid restriction & $\begin{array}{l}\text { Euvolemic and } \\
\text { hypervolemic } \\
\text { hyponatremia }\end{array}$ & $\begin{array}{l}\text { Fluid restriction ( } 500-1000 \mathrm{~mL} \text { ) includes all fluids including } \\
\text { intravenous fluids. } \\
\text { Degree of fluid restriction depends on serum sodium level, } \\
\text { urine output and insensible fluid losses. } \\
\text { Fluid restriction to }<500 \mathrm{~mL} / \text { day of } 24 \text { h urine output is } \\
\text { recommended }\end{array}$ & $\begin{array}{l}\text { Rapid correction in case of } \\
\text { primary polydipsia. } \\
\text { Less likely to be effective if } 24 \mathrm{~h} \\
\text { urine output is }<1500 \mathrm{~mL}\end{array}$ \\
\hline Isotonic saline & $\begin{array}{l}\text { Hypovolemic } \\
\text { hyponatremia }\end{array}$ & Fluid resuscitation with $0.9 \%$ normal saline & $\begin{array}{l}\text { Ineffective and potentially } \\
\text { dangerous in euvolemic } \\
\text { hyponatremia. Should not } \\
\text { be used in hypervolemic } \\
\text { hyponatremia }\end{array}$ \\
\hline Electrolyte free water & $\begin{array}{l}\text { Management of } \\
\text { overcorrection }\end{array}$ & $\begin{array}{l}\text { Electrolyte free water } 10 \mathrm{~mL} / \mathrm{kg} \text { over one hour. } \\
\text { Desmopressin } 2 \mathrm{mcg} \text { i.v. every } 8 \mathrm{~h}\end{array}$ & Hyponatremia \\
\hline
\end{tabular}

${ }^{*}$ Total amount of $3 \% \mathrm{NaCl}$ to infuse $(\mathrm{mL})=($ desired change in serum $\mathrm{Na} \times 1000) / \Delta \mathrm{Na}{ }^{\dagger} .{ }^{\dagger} \Delta \mathrm{Na}$ (change in serum sodium per liter infused) $=\left(513^{\#}-\right.$ serum sodium $) /\left[\mathrm{TBW}(\mathrm{L})^{\star \star}+1\right] .{ }^{\#}$ Amount of sodium $(\mathrm{mEq})$ in $1 \mathrm{~L}$ of $3 \% \mathrm{NaCl}$. ${ }^{\star \star} \mathrm{TBW}(\mathrm{L})=$ weight $(\mathrm{kg}) \times 0.6$ (children, nonelderly men); 0.5 (nonelderly women, elderly men); or 0.45 (elderly women). SIAD: syndrome of inappropriate antidiuresis; TBW: total body water

used medication to treat SIAD, especially chronic disease, is the tetracycline antibiotic demeclocycline, which has the side effect of causing nephrogenic diabetes insipidus ${ }^{[34]}$. A few of the other side effects of demeclocycline include GI intolerance, renal toxicity, and photosensitivity. One should note, however, that its onset of action is delayed (typically 5 days or more), so it is not appropriate for the acute management of severe SIAD. Urea (available as prescription and over the counter) at a dose of 30-60 g/day has been used to induce osmotic diuresis in chronic hyponatremia. Side effects of urea include headache and GI irritation. Combining urea with $\mathrm{NaHCO}_{3}$, sucrose and citric acid (urea $10 \mathrm{~g}+\mathrm{NaHCO}_{3} 2 \mathrm{~g}+$ citric acid $1.5 \mathrm{~g}+$ sucrose $200 \mathrm{mg}$ ) improves the taste and makes it palatable. Addition of urea to orange juice could also help reduce the bitter taste. Fludrocortisone can increase serum sodium up to $5 \mathrm{mEq} / \mathrm{L}$ and salt supplementation $(\mathrm{NaCl}$ $1 \mathrm{~g}$ po TID) can also be considered ${ }^{[35]}$.

Fluid restriction is preferred in patients with expanded extracellular volume. Intake and output of urine should be monitored closely. Free water intake should be $500 \mathrm{~mL}$ less than the urine output. Patients with reduced extracellular volume and hemodynamic instability require rapid fluid restoration. Extracellular volume is restored with i.v. infusion of $0.9 \%$ saline or a balanced crystalloid solution. As volume repletion suppresses vasopressin release in hypovolemia, close monitoring of serum sodium and urine output is required to avoid hypernatremia in the presence of increased free water clearance ${ }^{[10]}$. Potassium deficiency should be replaced. Since potassium is osmotically active and can be exchanged with sodium, overcorrection of sodium is a concern in case of potassium repletion. 


\section{CENTRAL PONTINE MYELINOLYSIS}

The rapid correction of hyponatremia by any means can cause central pontine myelinolysis, also known as osmotic demyelination syndrome ${ }^{[36]}$. It is characterized by severe and often irreversible neurologic sequelae such as dysarthria, dysphagia, psychiatric disturbances, spastic paraplegia or quadriplegia, seizures, pseudobulbar palsy, and altered mental status. Symptoms of osmotic demyelination occur 4-6 days after rapid overcorrection ${ }^{[37]}$. Therefore, the overall goal of treatment should be to avoid increasing the serum sodium levels by more than $0.5 \mathrm{mEq} / \mathrm{L} / \mathrm{h}$ (or $10 \mathrm{mEq} / \mathrm{L} /$ day) and $8 \mathrm{mEq}$ per subsequent day ${ }^{[10,38]}$. However, some experts recommend an even more conservative therapeutic goal of an increase of no more than $8 \mathrm{mEq} / \mathrm{day}^{[33,39]}$. Serum sodium levels should be assessed every 2-4 h during the initial stages of treatment for severe symptomatic hyponatremia. Desmopressin, 1-2 $\mu \mathrm{g}$ parenterally every 6-8 $\mathrm{h}$, has been used along with hypertonic saline to reduce the risk of rapid correction, although further studies are needed to confirm the effectiveness of this approach $^{[40]}$. In addition to the degree of hyponatremia and rate of hyponatremia development, factors that also increase the risk of osmotic demyelination syndrome include liver disease, concurrent use of thiazide diuretics, and antidepressants. Suppression of AVP release with volume repletion in patients with reduced extracellular volume increases the risk of rapid correction of sodium due to increase free water clearance. In addition to close monitoring of urine output, serum sodium should be monitored every $2 \mathrm{~h}^{[10]}$.

\section{VAPTANS: MECHANISM OF ACTION, CLINICAL IMPLICATIONS AND FUTURE PERSPECTIVES}

Vaptans are AVP receptor antagonists that are FDA-approved for clinical use in patients with euvolemic and hypervolemic hyponatremia. AVP antagonists block vasopressin receptors on principal cells in the renal collecting tubules. Inhibition of AVP receptors blocks increase in cAMP and protein kinase A that leads to reduced translocation of aquaporin 2 (water channels) to the luminal membrane. Binding of vaptans decreases the permeability of the apical membrane to water. Vaptans are aquaretic agents because they enhance electrolyte free-water clearance without associated natriuresis ${ }^{[13]}$. Vaptans are utilized to reduce fluid restriction in patients with symptomatic mild to moderate chronic hyponatremia due to SIAD and heart failure ${ }^{[39]}$. Conivaptan is a non-peptide dual V1A/V2 AVP receptor antagonist. Conivaptan, given as an initial i.v. bolus followed by a continuous infusion, increases serum sodium up to $6 \mathrm{mEq} / \mathrm{L}$ as compared with placebo. Use of i.v. conivaptan can be associated with rapid correction of hyponatremia, transient symptomatic hypotension, and peripheral i.v. site reaction. Patients receiving conivaptan through a central venous catheter did not have any adverse reactions ${ }^{[41]}$. The most common reason for discontinuation of conivaptan is infusion site reaction ${ }^{[42]}$. Tolvaptan is an oral V2-receptor antagonist also approved for use in euvolemic or hypervolemic hyponatremia. The most common adverse effects reported during tolvaptan use are thirst and dry mouth. Although it is an oral medication, the use of tolvaptan should be limited to the inpatient setting to monitor for overcorrection of serum sodium following administration.

Vaptan use has been associated with alanine aminotransferase elevation and hepatotoxicity with long term use. During treatment with vaptans, in addition to close monitoring of serum sodium, urine osmolality should be monitored. The dose of vaptan should be increased if the urine osmolality remains high. If urine osmolality is low, fluid intake should be restricted ${ }^{[13]}$. The clinical trials evaluating these agents did not include patients with serum sodium less than $115 \mathrm{mEq} / \mathrm{L}^{[43]}$. Caution is advised in patients with acute symptomatic hyponatremia, underlying liver disease, and volume depletion ${ }^{[39]}$. Post hoc analysis from the trial ACTIVE showed a reduction in mortality $\sim 50 \%$ in patients with congestive heart failure after the correction of hyponatremia with the use of tolvaptan. The EVERST trial evaluated the role of tolvaptan (30 mg Po QD) in cardiac failure patients for 2 years. There was no difference in all cause mortality in tolvaptan treated patients versus placebo ${ }^{[41]}$.

In the SALT WATER trial, long term use of tolvaptan (2 years) was evaluated for safety and efficacy in patients with euvolemic and hypervolemic hyponatremia. Hypernatremia was reported in only one patient. 
As compared with fluid restriction, lithium and urea, vaptans offer a therapeutic option that is pathophysiologically focused, potent and effective $e^{[41]}$. Despite efficacy of vaptans in improving serum sodium, clinical practice guideline on the diagnosis and treatment of hyponatremia do not recommend the use of vaptans due to concern for overcorrection of sodium and lack of mortality benefit ${ }^{[23]}$. The safety and efficacy of tolvaptan was evaluated in a post hoc subgroup analysis of the patients with cancer in SALT-1 (study of ascending levels of tolvaptan in hyponatremia) and SALT-2 clinical trials. Baseline sodium in the cohort of the SALT trials was $130 \mathrm{mEq} / \mathrm{L}$. A $15 \mathrm{mg}$ dose of tolvaptan was titrated up to 30 or $60 \mathrm{mg}$ over 4 days if the increase in serum sodium was $<5 \mathrm{mEq} / \mathrm{L}$ in the prior $24 \mathrm{~h}$. Tolvaptan was withheld or reduced and fluid intake was increased if serum sodium was $>145 \mathrm{mEq} / \mathrm{L}$. Serum sodium normalized to $>135 \mathrm{mEq} / \mathrm{L}$ in $66.6 \%$ of the patients by day 30 . Serum sodium exceeded the desired rate of correction $(>8 \mathrm{mEq} / \mathrm{L}$ over the first $8 \mathrm{~h}$ of therapy or $>12 \mathrm{mEq} / \mathrm{L}$ over $24 \mathrm{~h}$ ) in $1.8 \%$ of patients. None of these patients developed any symptoms of osmotic demyelination syndrome ${ }^{[6]}$.

In our experience, vaptans are well tolerated by cancer patients and offer a therapeutic option in patients with euvolemic and hypervolemic hyponatremia when fluid restriction alone is insufficient to increase serum sodium levels or to avoid the discomfort associated with fluid restriction. Although the vaptans are well tolerated and effective, their high cost continues to be a limitation for routine use. In a post hoc analysis, economic models from SALT-1, SALT-2 and EVERST reported decrease in length of stay in the hospital and hospital cost savings with tolvaptan use ${ }^{[44]}$. To reduce the risk of hyponatremia all i.v. medications should be concentrated and hypotonic i.v. fluids should be avoided in hospitalized patients, e.g., perioperatively, during cancer chemotherapy, bronchitis, pneumonia or lung disease ${ }^{[45]}$.

\section{CONCLUSION}

Oncology patients with hyponatremia need close monitoring of fluid intake and output to prevent derangements in salt and volume balance. Hyponatremia in cancer patients is associated with advanced disease and poor prognosis. Improvement in serum sodium correlates with improved survival ${ }^{[9]}$. Whether the treatment of hyponatremia improves overall survival needs to be investigated. Proposed algorithms for the management of hyponatremia could be utilized in patients with cancer, recognizing that hyponatremia is of diverse etiology in this population. Use of therapeutic agents such as the vaptans offer a convenient, effective, and targeted approach to the management of hyponatremia. Further studies are likely to clarify cost effectiveness and safety concerns related to vaptan use in cancer patients.

\section{DECLARATIONS}

\section{Authors' contributions}

Wrote the first draft of the manuscript: Khan MI

Provided critical edits to the manuscript: Waguespack SG, Ahmed I

Approved the final version of the manuscript: Khan MI, Waguespack SG, Ahmed I

\section{Availability of data and materials}

Not applicable.

\section{Financial support and sponsorship}

Not applicable.

\section{Conflicts of interest}

All authors declared that there are no conflicts of interest.

\section{Ethical approval and consent to participate}

Not applicable. 


\section{Consent for publication}

Not applicable.

\section{Copyright}

(c) The Author(s) 2019.

\section{REFERENCES}

1. Onitilo AA, Kio E, Doi SA. Tumor-related hyponatremia. Clin Med Res 2007;5:228-37.

2. Stelfox HT, Ahmed SB, Khandwala F, Zygun D, Shahpori R, et al. The epidemiology of intensive care unit-acquired hyponatraemia and hypernatraemia in medical-surgical intensive care units. Crit Care 2008;12:R162.

3. Funk GC, Lindner G, Druml W, Metnitz B, Schwarz C, et al. Incidence and prognosis of dysnatremias present on ICU admission. Intensive Care Med 2010;36:304-11.

4. Berardi R, Caramanti M, Castagnani M, Guglielmi S, Marcucci F, et al. Hyponatremia is a predictor of hospital length and cost of stay and outcome in cancer patients. Support Care Cancer 2015;23:3095-101.

5. Doshi SM, Shah P, Lei X, Lahoti A, Salahudeen AK. Hyponatremia in hospitalized cancer patients and its impact on clinical outcomes. Am J Kidney Dis 2012;59:222-8.

6. Gralla RJ, Ahmad F, Blais JD, Chiodo J 3rd, Zhou W, et al. Tolvaptan use in cancer patients with hyponatremia due to the syndrome of inappropriate antidiuretic hormone: a post hoc analysis of the SALT-1 and SALT-2 trials. Cancer Med 2017;6:723-9.

7. Castillo JJ, Vincent M, Justice E. Diagnosis and management of hyponatremia in cancer patients. Oncologist 2012;17:756-65.

8. Platania M, Verzoni E, Vitali M. Hyponatremia in cancer patients. Tumori 2015;101:246-8.

9. Balachandran K, Okines A, Gunapala R, Morganstein D, Popat S. Resolution of severe hyponatraemia is associated with improved survival in patients with cancer. BMC Cancer 2015;15:163.

10. Spasovski G, Vanholder R, Allolio B, Annane D, Ball S, et al. Clinical practice guideline on diagnosis and treatment of hyponatraemia. Nephrol Dial Transplant 2014;29 Suppl 2:11-39.

11. Berardi R, Santoni M, Newsom-Davis T, Caramanti M, Rinaldi S, et al. Hyponatremia normalization as an independent prognostic factor in patients with advanced non-small cell lung cancer treated with first-line therapy. Oncotarget 2017;8:23871-9.

12. Hansen O, Sorensen P, Hansen KH. The occurrence of hyponatremia in SCLC and the influence on prognosis: a retrospective study of 453 patients treated in a single institution in a 10-year period. Lung Cancer 2010;68:111-4.

13. Lehrich RW, Ortiz-Melo DI, Patel MB, Greenberg A. Role of vaptans in the management of hyponatremia. Am J Kidney Dis 2013;62:364-76

14. Maesaka JK, Imbriano L, Mattana J, Gallagher D, Bade N, et al. Differentiating SIADH from cerebral/renal salt wasting: failure of the volume spproach and need for a new spproach to hyponatremia. J Clin Med 2014;3:1373-85.

15. Robertson GL. Regulation of arginine vasopressin in the syndrome of inappropriate antidiuresis. Am J Med 2006;119(7 Suppl 1):S36-42

16. Moritz ML. Syndrome of inappropriate antidiuresis. Pediatr Clin North Am 2019;66:209-26.

17. Kamoi K, Ebe T, Kobayashi O, Ishida M, Sato F, et al. Atrial natriuretic peptide in patients with the syndrome of inappropriate antidiuretic hormone secretion and with diabetes insipidus. J Clin Endocrinol Metab 1990;70:1385-90.

18. Hillier TA, Abbott RD, Barrett EJ. Hyponatremia: evaluating the correction factor for hyperglycemia. Am J Med 1999;106:399-403.

19. Verbalis JG, Goldsmith SR, Greenberg A, Korzelius C, Schrier RW, et al. Diagnosis, evaluation, and treatment of hyponatremia: expert panel recommendations. Am J Med 2013;126 (10 Suppl 1):S1-42.

20. Miller M. Syndromes of excess antidiuretic hormone release. Crit Care Clin 2001;17:11-23.

21. Cerdà-Esteve M, Cuadrado-Godia E, Chillaron JJ, Pont-Sunyer C, Cucurella G, et al. Cerebral salt wasting syndrome: review. Eur J Intern Med 2008;19:249-54.

22. Holland-Bill L, Christiansen CF, Farkas DK, Donskov F, Jorgensen JOL, et al. Diagnosis of hyponatremia and increased risk of a subsequent cancer diagnosis: results from a nationwide population-based cohort study. Acta Oncol 2018;57:522-7.

23. Henry DA. In the clinic: hyponatremia. Ann Intern Med 2015;163:1-19.

24. Harrigan MR. Cerebral salt wasting syndrome. Crit Care Clin 2001;17:125-38

25. Yee AH, Burns JD, Wijdicks EF. Cerebral salt wasting: pathophysiology, diagnosis, and treatment. Neurosurg Clin N Am 2010;21:33952.

26. Betjes MG. Hyponatremia in acute brain disease: the cerebral salt wasting syndrome. Eur J Intern Med 2002;13:9-14

27. Palmer BF. Hyponatremia in the intensive care unit. Semin Nephrol 2009;29:257-70.

28. Rivkees SA. Differentiating appropriate antidiuretic hormone secretion, inappropriate antidiuretic hormone secretion and cerebral salt wasting: the common, uncommon, and misnamed. Curr Opin Pediatr 2008;20:448-52.

29. Gurnurkar S, Villacres S, Warner L, Chegondi M. Successful use of fludrocortisone in a child with refractory cerebral salt wasting syndrome: a case report and review of literature. Cureus 2018;10:e3505.

30. Refardt J, Winzeler B, Christ-Crain M. Copeptin and its role in the diagnosis of diabetes insipidus and the syndrome of inappropriate antidiuresis. Clin Endocrinol (Oxf) 2019;91:22-32.

31. Hoorn EJ, Zietse R. Diagnosis and treatment of hyponatremia: compilation of the guidelines. J Am Soc Nephrol 2017;28:1340-9.

32. Janicic N, Verbalis JG. Evaluation and management of hypo-osmolality in hospitalized patients. Endocrinol Metab Clin North Am 2003;32:459-81.

33. Adrogue HJ, Madias NE. Hyponatremia. N Engl J Med 2000;342:1581-9.

34. Cherrill DA, Stote RM, Birge JR, Singer I. Demeclocycline treatment in the syndrome of inappropriate antidiuretic hormone secretion. 
Ann Intern Med 1975;83:654-6.

35. Mori T, Katayama Y, Kawamata T, Hirayama T. Improved efficiency of hypervolemic therapy with inhibition of natriuresis by fludrocortisone in patients with aneurysmal subarachnoid hemorrhage. J Neurosurg 1999;91:947-52.

36. Lampl C, Yazdi K. Central pontine myelinolysis. Eur Neurol 2002;47:3-10.

37. Dokmak A, Madias NE. Hyponatremia and in-hospital falls and fractures in older adults. J Am Geriatr Soc 2019;67:1752-3.

38. Sterns RH. The management of symptomatic hyponatremia. Semin Nephrol 1990;10:503-14.

39. Adrogue HJ, Madias NE. Diagnosis and treatment of hyponatremia. Am J Kidney Dis 2014;64:681-4.

40. Sood L, Sterns RH, Hix JK, Silver SM, Chen L. Hypertonic saline and desmopressin: a simple strategy for safe correction of severe hyponatremia. Am J Kidney Dis 2013;61:571-8.

41. Gross PA, Wagner A, Decaux G. Vaptans are not the mainstay of treatment in hyponatremia: perhaps not yet. Kidney Int 2011;80:594-600.

42. Verbalis JG, Zeltser D, Smith N, Barve A, Andoh M. Assessment of the efficacy and safety of intravenous conivaptan in patients with euvolaemic hyponatraemia: subgroup analysis of a randomized, controlled study. Clin Endocrinol (Oxf) 2008;69:159-68.

43. Schrier RW, Gross P, Gheorghiade M, Berl T, Verbalis JG, et al. Tolvaptan, a selective oral vasopressin V2-receptor antagonist, for hyponatremia. N Engl J Med 2006;355:2099-112.

44. Chiong JR, Kim S, Lin J, Christian R, Dasta JF. Evaluation of costs associated with tolvaptan-mediated length-of-stay reduction among heart failure patients with hyponatremia in the US, based on the EVEREST trial. J Med Econ 2012;15:276-84.

45. Peri A. Clinical review: the use of vaptans in clinical endocrinology. J Clin Endocrinol Metab 2013;98:1321-32.

46. Khan MI, Dellinger RP, Waguespack SG. Electrolyte disturbances in critically Ill cancer patients: an endocrine perspective. J Intensive Care Med 2018;33:147-58. 